University of Michigan Law School

University of Michigan Law School Scholarship Repository

\title{
The Legal Status of Abstract Books, Literary Property, Implied Contract of Secrecy, Unfair Trade
}

\author{
Edgar N. Durfee \\ University of Michigan Law School
}

Available at: https://repository.law.umich.edu/articles/1247

Follow this and additional works at: https://repository.law.umich.edu/articles

Part of the Commercial Law Commons

\section{Recommended Citation}

Durfee, Edgar N. "The Legal Status of Abstract Books, Literary Property, Implied Contract of Secrecy, Unfair Trade." Mich. L. Rev. 18 (1920): 415-8.

This Response or Comment is brought to you for free and open access by the Faculty Scholarship at University of Michigan Law School Scholarship Repository. It has been accepted for inclusion in Articles by an authorized administrator of University of Michigan Law School Scholarship Repository. For more information, please contact mlaw.repository@umich.edu. 
The Legal Status of Abstract Books-Literary Property, Implifed Contract of Secrecy, Unfair Trade.-A recent case before the Supreme Court of Washington raises some novel and interesting questions. A company engaged in the abstract business mortgaged its "records, books, plats." After suit was commenced to foreclose the mortgage, the mortgagor, who remained in possession, made photographic copies of the records and sold them to the defendant who had notice of the mortgage of the originals. The foreclosure resulted in a sale of the property, described as in the mortgage, to the plaintiff. Whether plaintiff knew at this time of the existence of the copies does not appear. Plaintiff is using the original records in the conduct of an abstract business and defendant is using the copies in competition with him. The action was brought to recover the copies. The court holds that it cannot be maintained because, assuming that the mortgage included the copies, the copies were not embraced in the sheriff's sale. It asserts, obiter, that the mortgagee might have enjoined the making of the copies, and it raises, but 
declines to answer, some other questions concerning the rights of the parties. Wintler Abstract Co. v. Sears (Wash., 19r9), 184 Pac. 309.

If it was procedurally impossible to treat the action as an equitable suit to compel surrender of the copies for destruction, the decision was clearly right. There would seem to be no theory which would support a conmon law possessory action. The doctrine of accession most nearly suffices but, while the case bears some analogy to those of young of animals, it is impossible to extend that doctrine to embrace reproductions by the hand of man, involving neither mutilation of the original nor confusion.

But what of other remedies? Ownership of things ordinarily involves no exclusive right to photograph or copy the things, though the exercise of the exclusive right of possession may make photographing or copying by others physically impossible. Sports Press Agency v. "Our Dogs" Publishing Co. [1916], 2 K. B. 880; Flagg Mfg. Co. v. Holway, 178 Mass. 83; Keystonc Type Foundry v. Portland Publishing Co., 186 Fed. 690. A fortiori, the limitcd interest of a mortgagee ordinarily gives no such exclusive right. But the subject of this mortgage was peculiar, and upon its peculiarity the mortgagee, and the purchaser under him, may well base a claim to protection from the dishonest acts of the mortgagor and his purchaser. There are three distinct theories which might plausibly be argued: (I) literary property, (2) implied contract, (3) unfair competition.

In the facts which constitute the subject matter of abstract books, no one. of course, can have any property. But, as a compilation of information, such books would seem to be within the doctrine of literary property. Dart v. Woodhouse, 40 Mich. 399; Perry v. Big Rapids, 67 Mich. 146; Banker v. Caldwell, 3 Minn. 94; Vernon Abstract Co. v. Waggoner Title Co., 49 Tex. Civ. App. 144 (semble). In Leon Abstract Co. v. Equalization Board, $86 \mathrm{Ia}$. 127, a contrary conclusion was based on the fact that such books are not a "work of genius or the development of new thoughts or ideas" (dissenting opinion in Perry v. Big Rapids, supra, adopted by this court), and upon the fact that the manuscript was not designed for publication but was designed to be kept from publication. Both lines of reasoning are unsound. Bleistein v. Donaldson Lithographic Co., 188 U. S. 239; Prince Albert v. Strange, 2 DeG. \& Sm. 652. The Supreme Court of Washington, however, is committed to this view. Booth Co. v. Phelps, 8 Wash. 549 .

If the theory of Jiterary property be admitted at all, the next question is whether there has been such a general publication as to destroy it. In $V e r-$ non Abstract Co. v. Waggoner Title Co., supra, it was held that furnishing abstracts to the general public was such a publication, the limited purpose of the publication being considered immaterial. The opposite is implicit in the Michigan and Minnesota decisions, and the case would seem to be much stronger than some of the cases of limited publication, e. g., stage production of a play, Tompkins v. Halleck, 133 Mass. 32; or delivery to university classes of a lecture, Caird v. Sime, 12 App. Cas. 326 .

Literary property can be transferred without any particular formality and, although sale of a manuscript or painting may be made with reservation of 
the right of reproduction, such a sale may imply an assignment of that right. Parton v. Prang, 3 Cliff. 537. In view of the comparative uselessness of abstract books without the exclusive right of reproduction, the mortgage and the sheriff's sale of the books can easily be said to impliedly embrace the literary property. The right of user, as incident to the right of possession, may remain in the mortgagor until foreclosure, but this cannot embrace the right to make copies for use in derogation of the mortgage of the literary property. Plaintiff, then, is entitled to enjoin the use of the copies by the mortgagor or by any purchaser with notice, and is probably entitled to have the copies destroyed. Prince Albert v. Strange, supra.

If the theory of literary property fails, plaintiff may fall back on implied contract or trust. In the same way, some courts dealing with the right to prevent general use by a professional photographer of a portrait photograph, hesitating to recognize a right of privacy, have based relief on implied contract or breach of confidence. Pollard v. Photographic Co., I. R. $40 \mathrm{Ch}$. Div. 345. Plaintiff's theory is that, in making the mortgage, the mortgagor impliedly promised not to make copies of the records to be used by himself or any one else in competition with the transferee of the originals. Here, again, the basis for implication is principally the comparative uselessness of the records if copies are at large. Our case is in many respects analogous to, if indeed it is not parcel of, the cases on trade secrets. A trade secret is any information valuable to a business enterprise which the possessor thereof withholds from the general public. Its legal protection depends entirely upon contract or trust, express or implied, and implications are freely indulged in this field, 44 L. R. A. (N.S.) I160, note. In the usual case, the information is disclosed by the original possessor to an employee and the latter is charged with the obligation not to disclose or to use for himself such information. There the obligation is implied from the confidential nature of the disclosure. But the principle has been reversed where the original possessor of the information has sold the information to another. Here the implied obligation arises from the equity against derogating from one's own grant. Pomeroy Ink Co. v. Pomeroy, 77 N. J. Eq. 293. That is precisely our case, and it seems easy enough to make out the implied obligation of mortgagor to mortgagee. But the latter has lost all right to complain, having been paid by the foreclosure, and, on the other hand, no relief is adequate which does not reach the purchaser from the mortgagor. Can we connect the benefits and burdens of the implied contract with the plaintiff and defendant, respectively? It is submitted that the doctrine of Tulk v. Moxhay is adequate to the task. This doctrine applies to personal property as well as land, though in a large percentage of the cases which have come before the courts relief has been denied because the covenant was held to contravene public policy. Murphy v. Christion Press Co., 38 N. Y. App. Div. 426 . That "covenants" may be implied, is well settled. 45 L. R. A. (N.S.) 962 , note: The covenant touches and concerns the records in a most vital way Though it creates a mere "easement of monopoly," it is easily distinguishable from Norcross v. James, I40 Mass. I\&, in that monopoly, more or less extensive, is here of the very essence of 
normal enjoyment. A fortiori, the case is within those authorities opposed to Nercross v. James. The benefit of the covenant, having been from the first so vitally connected with the records, would pass with the records without express assignment. Jolir, Restrictive Covenants, 43. And see Vulcan Detiming Co. v. American Can Co., 67 N. J. Eq. 243; Pomeroy Ink Co. v. Pameroy, supra; both holding that the benefit of an implied obligation not to use or disclose trade secrets passes with the obligee's business. The burden of the covenant, at first personal, attached to the copies when made, and yassed with the copies to the purchaser without notice. Lewis v. Gollner, 129 N. Y. 227. And see the trade secret cases where relief has been given third parties with notice. Tabor v. Hoffman, II8 N. Y. 30; Pressed Steel Car Co. v. Standard Stel Car Co., 210 Pa. 464.

If it be thought that both these theories are pressed too far, the plaintiff falls back on the doctrine of unfair competition, as applied in Associated Press v. International News Service, 248 U. S. 215 . The similarity of the cases, assuming that neither literary property nor implied contract can be made out here, is striking. The conspicuous difference, that there the parties were strangers; while here they are related through the mortgage and subsequent sales, makes our case the stronger. The formula of the Press Case, that one shall not "reap where he has not sown," needs only to be inverted-one shall not reap where he has bargained and sold his sowing. It may, of course, be doubted whether the court was justified in its application of this ethical principle, and it is quite certain that this ethical principle cannot be applied generally without overturning much settled law. See dissenting opinion of Brandeis, J., and note, 13 III. L. REv. 708. But the ethics of our case is at least as clear as that of the Associated Press case.

It may be admitted that this case taxes our legal dogmas, but it will be a reproach to the law if, when the plaintiff's case is properly presented, he cannot be given relief.

E. N. D. 